\title{
NOVEJŠE SMERI V KRASOSLOVNIH RAZISKAVAH
}

\author{
Andrej Kranjc \\ Akad. dr., Inštitut za raziskovanje krasa ZRC SAZU, Titov trg 2, \\ 6230 Postojna, Slovenija. \\ e-mail: kranjc@zrc-sazu.si
}

\begin{abstract}
Izvleček
Krasoslovje je integralni sistem znanosti o krasu, močno podobno fizični geografiji. Med vodilnimi krasoslovci je vrsta geografov, tudi na Slovenskem, npr. prof. Gams. Na podlagi bibliografije je mogoče izdvojiti nekaj novejših smeri v krasoslovnih raziskavah: nastanek in razvoj krasa, speleogeneza, vloga mikrobiologije, luminiscenca, klastični sedimenti, minerali, nastanek in razvoj kapnikov, merjenje odlaganja sige, kemizem kapnikov, absolutna datacija sedimentov. Hidrološke raziskave so smer, ki jo bo treba obdržati in okrepiti. Regionalno gledano je "odkrivanj" manj, čeprav se krasoslovci podajajo v najbolj oddaljene dele sveta. Med objavljenimi deli narašča število iz drugih delov sveta in so "klasična" kraška ozemlja zapostavljena. Sinteza in sintetični prispevki so tista dejavnost, ki bi se je geografi lahko v večji meri lotili in kar jim (naj) zagotavlja tudi njihova osnovna izobrazba.
\end{abstract}

Ključne besede: krasoslovje, speleologija, bibliografski pregled, krasoslovne raziskave.

\section{NEW TRENDS IN KARSTOLOGICAL RESEARCH}

\begin{abstract}
Karstology is an integrated system of sciences related to karst, similar to physical geography. Among the most important karstologists there are many geographers, in Slovenia also, for example Prof. Gams. Browsing the bibliography, some new topics in karstological research stand out such as genesis and evolution of karst, speleogenesis, importance of microbiology, luminescence, clastic sediments, minerals, origin and development of speleothems, measurements of flowstone deposition, chemistry of speleothems, absolute dating of sediments. Hydrological research has to be carried out and to intensify even. From regional point of view there are less and less new discoveries and the "classical" karst countries are neglected comparing with other parts of the World. Synthesis of acquired knowledge should be the task of geographers due to their fundamental education.
\end{abstract}

Key words: karstology, speleology, bibliographical review, karstological research. 